\title{
Non-typhoidal Salmonella severe sepsis in an immunocompetent young woman
}

\author{
Joana Ramalho, João Correia
}

Department of Medicine, Centro Hospitalar do PortoHospital de Santo António, Porto, Portugal

\section{Correspondence to}

Dr Joana Ramalho, jasorblue@gmail.com
To cite: Ramalho J, Correia J. BMJ Case Rep Published online: [please include Day Month Year] doi:10.1136/bcr-2013008773

\section{DESCRIPTION}

A previously healthy, immunocompetent 24-year-old woman presented with onset of diarrhoea (without blood or mucus), vomiting and abdominal pain within $6 \mathrm{~h}$ of evolution. She stated a consumption of well water and tomato pulp a few days ago and no recent history of travel abroad.

At hospital admission, she was dehydrated, with shivering, tachycardia, hypotension and painful abdominal palpation, but without signs of peritoneal irritation.

In a few hours, there occurred clinical deterioration with shock, acute abdomen with peritoneal irritation and pancytopenia.

CT showed ascites and marked ileo-colon oedema and distension (figures 1 and 2). Stool and blood cultures turned positive for non-typhoidal salmonella (NTS), D group.

She went on vasoactive amine support and completed 14 days of ciprofloxacin with gradual improvement.

NTS serotypes are major causes of food-borne infections, which most often result in self-limited gastroenteritis. However, serious extraintestinal manifestations may occur, such as bacteraemia and subsequent focal infections. ${ }^{1}$

Despite the worldwide increasing prevalence of NTS infection among immunocompromised patients owing to conditions such as HIV infection, this entity remains rare in immunocompetent persons. $^{2}$

Hohmann et al ${ }^{1}$ report a 5\% NTS bacteraemia frequency in individuals with gastrointestinal illness and that most patients have extremes of age and

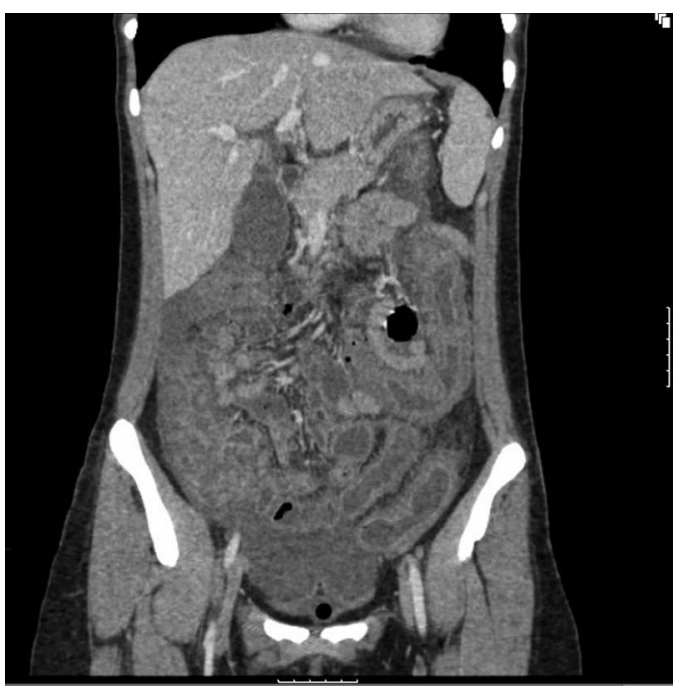

Figure 1 CT coronal image showing marked ileocolon oedema and distension.

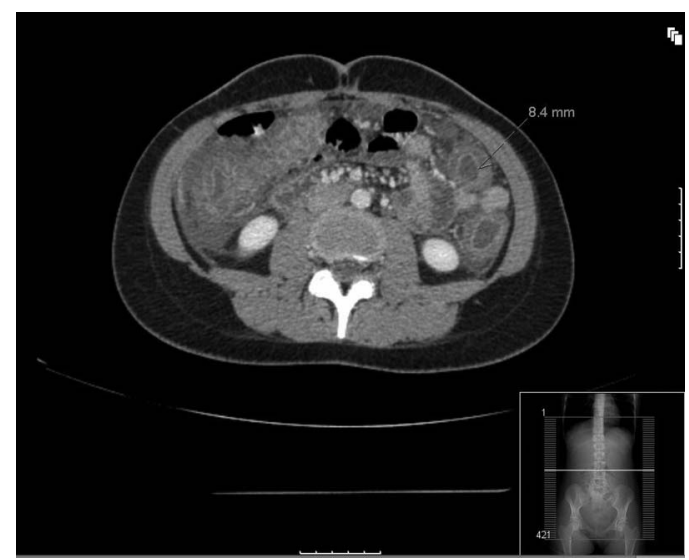

Figure 2 CT transversal image showing colon oedema.

immunosuppression, such as malignancies, HIV infection or connective-tissue disorders. ${ }^{3}$

This case illustrates a severe invasive disease with haematogenous spread, septic shock and marked intestinal distension with risk of rupture, in an immunocompetent woman without comorbidities, from a pathogen that usually causes self-limiting gastrointestinal manifestations.

\section{Learning points}

Non-typhoidal salmonella (NTS) infection often results in self-limited acute gastroenteritis; however, invasive disease can occur with bacteraemia and subsequent focal infections.

- NTS invasive disease is a rare entity in immunocompetent persons.

- Worldwide, there is an increasing prevalence of NTS infection among immunocompromised patients because of conditions such as HIV infection.

Competing interests None.

Patient consent Obtained.

Provenance and peer review Not commissioned; externally peer reviewed.

\section{REFERENCES}

1 Hohmann EL. Nontyphoidal salmonellosis. Clin Infect Dis 2001;32:263-9.

2 Kato $\mathrm{H}$, Ueda A, Tsukiji J, et al. Salmonella enterica serovar Ohio septic arthritis and bone abscess in an immunocompetent patient a case report. J Med Case Rep 2012;6:204-1.

3 Chen PL, Chang CM, Wu CJ, et al. Extraintestinal focal infections in adults with nontyphoid Salmonella bacteraemia: predisposing factors and clinical outcome. J Intern Med 2007;261:91-100. 
Copyright 2013 BMJ Publishing Group. All rights reserved. For permission to reuse any of this content visit http://group.bmj.com/group/rights-licensing/permissions.

BMJ Case Report Fellows may re-use this article for personal use and teaching without any further permission.

Become a Fellow of BMJ Case Reports today and you can:

- Submit as many cases as you like

- Enjoy fast sympathetic peer review and rapid publication of accepted articles

- Access all the published articles

- Re-use any of the published material for personal use and teaching without further permission

For information on Institutional Fellowships contact consortiasales@bmjgroup.com

Visit casereports.bmj.com for more articles like this and to become a Fellow 